\title{
Diversity of springtails (Hexapoda) according to a altitudinal gradient
}

\author{
Arturo García-Gómez ${ }^{(1)}$, Gabriela Castaño-Meneses ${ }^{(1,2)}$ and José G. Palacios-Vargas ${ }^{(1)}$ \\ (1)Universidad Nacional Autónoma de México (UNAM), Ecología y Sistemática de Microartrópodos, Departamento de Ecología y Recursos \\ Naturales, Facultad de Ciencias, Ciudad Universitaria, 04510 México, D. F. E-mail: gab12y@yahoo.com.mx; jgpv@hp.fciencias.unam.mx \\ (2) UNAM, Unidad Multidisciplinaria de Docencia e Investigación, Facultad de Ciencias, Campus Juriquilla, Boulevard Juriquilla, 3001, \\ C.P. 76230, Querétaro, Querétaro, México. E-mail: gcm@hp.fciencias.unam.mx
}

\begin{abstract}
The objective of this work was to elevate gradient effect on diversity of Collembola, in a temperate forest on the northeast slope of Iztaccíhuatl Volcano, Mexico. Four expeditions were organized from November 2003 to August 2004, at four altitudes (2,753, 3,015, 3,250 and 3,687 m a.s.l.). In each site, air temperature, $\mathrm{CO}_{2}$ concentration, humidity, and terrain inclination were measured. The influence of abiotic factors on faunal composition was evaluated, at the four collecting sites, with canonical correspondence analyses (CCA). A total of 24,028 specimens were obtained, representing 12 families, 44 genera and 76 species. Mesaphorura phlorae, Proisotoma ca. tenella and Parisotoma ca. notabilis were the most abundant species. The highest diversity and evenness were recorded at $3,250 \mathrm{~m}\left(\mathrm{H}^{\prime}=2.85 ; \mathrm{J}^{\prime}=0.73\right)$. Canonical analyses axes 1 and 2 of the CCA explained $67.4 \%$ of the variance in species composition, with $\mathrm{CO}_{2}$ and altitude best explaining axis 1, while slope and humidity were better correlated to axis 2 . The results showed that $\mathrm{CO}_{2}$ is an important factor to explain Collembola species assemblage, together with slope and humidity.

Index terms: Collembola, canonical correspondence analysis, $\mathrm{CO}_{2}$, mesofauna communities, spatial variation.

\section{Diversidade de colêmbolos (Hexapoda) de acordo com o gradiente de altitude}

Resumo - O objetivo deste trabalho foi avaliar o efeito do gradiente de elevação na diversidade de Collembola, em uma floresta temperada no Vulcão Iztaccíhuatl, México. Quatro expedições foram organizadas de novembro 2003 a agosto 2004 , em quatro altitudes $(2.753,3.015,3.250$ e $3.687 \mathrm{~m})$. Em cada local foram medidas a temperatura, a concentração de $\mathrm{CO}_{2} \mathrm{e}$ a umidade do ar, além da inclinação do terreno. A influência de fatores abióticos na composição da fauna foi avaliada nos quatro locais de coleta, por meio da análise de correspondência canônica. Coletaram-se 24.028 espécimes, distribuídos em 12 famílias, 44 gêneros e 76 espécies. Mesaphorura phlorae, Proisotoma ca. tenella e Parisotoma ca. notabilis foram as espécies mais abundantes. A diversidade e a equitabilidade mais elevadas foram registradas a $3.250 \mathrm{~m}$ $\left(\mathrm{H}^{\prime}=2.85 ; \mathrm{J}^{\prime}=0.73\right)$. A análise canônica mostrou que os eixos de correspondências 1 e 2 , juntos, explicam $67.4 \%$ da variação na composição específica, em que o $\mathrm{CO}_{2}$ e a altitude explicam melhor o eixo 1 , ao passo que a inclinação e a umidade estão mais bem relacionadas ao eixo 2. Os resultados mostraram que o $\mathrm{CO}_{2}$ é um fator importante para explicar o agrupamento das espécies de Collembola, juntamente com a inclinação e a umidade.
\end{abstract}

Termos para indexação: Collembola, análise de correspondência canônica, $\mathrm{CO}_{2}$, comunidades da mesofauna, variação espacial.

\section{Introduction}

Altitude is a very important parameter to understand the distribution of plants and animals. The patterns of diversity and distribution of vascular plants, birds, mammals and ants are influenced by altitude. These groups show a clear decrease in species diversity and abundance as one moves up along the altitudinal gradient (Heaney, 2001; O’Donnell \& Kumar, 2006).
Opposite to this, the edaphic microarthropods show an increase in diversity with elevation, up to a threshold beyond which there is an important decrease (Sadaka \& Ponge, 2003; Jing et al., 2005; Cutz-Pool et al., 2008).

Some important studies on altitudinal behavior of microarthropods were done by Sadaka \& Ponge (2003) and Jing et al. (2005) in Morocco and Tibet, respectively. In these studies, the authors took into account elevation and humidity. In Mexico, Palacios-Vargas (1985) 
studied the springtails of the Popocatépetl Volcano, along an elevational gradient, and their preference for certain biotopes such as soil, litter and moss.

In this contribution, we studied the Collembola communities in an elevational gradient, on the northeast slope of the Iztaccíhuatl Volcano, in order to understand how those communities are distributed in a temperate ecosystem.

\section{Materials and Methods}

Iztaccíhuatl Volcano $\left(19^{\circ} 10^{\prime} 98^{\prime \prime} \mathrm{N}, 98^{\circ} 38^{\prime} 30^{\prime \prime} \mathrm{W}\right)$ is located $64 \mathrm{~km}$ Southeast of Mexico City. Four collecting expeditions (November, 2003; and March, June and August, 2004) were performed at four different elevations: I, 2,753; II, 3,015; III, 3,250; and IV, 3,687 m. Elevation I, close to the National Park entrance, has the lowest slope and is frequently disturbed, due to the influx of many visitors and weekend campers (Table 1).

At each altitude, a square of $20 \times 1 \mathrm{~m}$ was selected, where 10 points were randomly chosen, and 20 samples were taken (10 of litter, 10 of soil). The surface of each sample was $225 \mathrm{~cm}^{2}$, and the total number of samples taken was 320. Samples were placed in plastic boxes $(15 \times 15 \times 15 \mathrm{~cm})$ until ready for processing. These samples were transported to Laboratorio de Ecología y Sistemática de Microartrópodos, at the Facultad de Ciencias, Universidad Nacional Autónoma de México (UNAM), and were processed using Berlese funnels during six days. After the fauna were extracted, the soil was analyzed for $\mathrm{pH}$ and organic carbon content, (Van Reeuwijk, 2002). In addition, samples of $100 \mathrm{~g}$ of soil were taken, in order to quantify soil moisture at each sample date. The soil analyses were performed at the Laboratorio de Edafología "Nicolás Aguilera", at UNAM.

Air temperature, $\mathrm{CO}_{2}$ concentration, and humidity were recorded for each sample point using a thermo-hydrometer (IAQ-Calc 8760y8762).
Collembola were sorted and quantified under a dissecting microscope; slides were prepared in Hoyer's solution after clarifying them in $\mathrm{KOH}$, and samples were identified with specialized keys (Palacios-Vargas, 1982; Mari Mutt \& Palacios-Vargas, 1987; Jordana et al., 1997; Christiansen and Bellinger, 1998; D'Haese, 1998; Sánchez, 1999; Janssens, 2007).

Evaluation of species diversity, at each elevation, was done with Shannon index and compared with modified t test (Magurran, 1988), using the correction of Bonferroni ( $\alpha=0.004$ ) for multiple comparisons. Dominance was estimated by Simpson's index (Zar, 1984; Magurran, 1988; Howell, 2002), and equitability by Pielou index.

The influence of elevation, date, environmental temperature, biotope (soil or litter), $\mathrm{CO}_{2}$, slope degree, $\mathrm{pH}$ (real and potential), carbon, and humidity on the Collembola community was evaluated by canonical correspondence analyses (CCA), performed with the software CANOCO Ver. 4 (ter Braak \& Smilauer, 1998).

\section{Results and Discussion}

Total density recorded in this study was 59,461 (average 13,346 \pm 64 ) individuals $\mathrm{m}^{-2}$. Density at each elevation was, $2,049 \pm 4$, at elevation I; 4,227 \pm 13 , at II; $2,369 \pm 3$, at III; and 4,701 \pm 9 individuals $\mathrm{m}^{-2}$ at IV.

A total of 86 species in 46 genera, belonging to 12 families of Collembola, were recorded (Table 2). The species Ceratophysella ca. brevis showed the highest density, followed by Desoria ca. flora, and Isotoma ca. notabilis. Species richness is shown in Table 2.

At elevation I, 45 species were found, 5 of which were present only at this altitude; Mesaphorura macrochaeta showed the highest density at this elevation (Table 2). At elevation II, 58 species were found, 8 of which were unique to this locality (all the from the Odontellidae

Table 1. General characteristics of the four sampling altitudes on the northeast slope of Iztaccíhuatl Volcano, Mexico.

\begin{tabular}{|c|c|c|c|c|}
\hline \multirow[t]{2}{*}{ Characteristic } & \multicolumn{4}{|c|}{ Sampling altitude } \\
\hline & $2,753 \mathrm{~m}$ & $3,015 \mathrm{~m}$ & $3,250 \mathrm{~m}$ & $3,687 \mathrm{~m}$ \\
\hline Vegetation & Quercus forest & Quercus forest & Abies-Pinus forest & Pinus forest \\
\hline Slope (degree) & 29 & 36 & 33 & 35 \\
\hline Coordinates & $19^{\circ} 12^{\prime} 40^{\prime \prime} \mathrm{N}$ & $19^{\circ} 12^{\prime} 30^{\prime \prime} \mathrm{N}$ & $19^{\circ} 12^{\prime} 16^{\prime \prime} \mathrm{N}$ & $19^{\circ} 12^{\prime} 06^{\prime \prime} \mathrm{N}$ \\
\hline & $98^{\circ} 44^{\prime} 02^{\prime \prime} \mathrm{W}$ & $98^{\circ} 43^{\prime} 41^{\prime \prime} \mathrm{W}$ & $98^{\circ} 42^{\prime} 54^{\prime \prime} \mathrm{W}$ & $98^{\circ} 41^{\prime} 25^{\prime \prime} \mathrm{W}$ \\
\hline Temperature $\left({ }^{\circ} \mathrm{C}\right.$ range $)$ & $22-45$ & $21-39$ & $21-40$ & $15-36$ \\
\hline Humidity $\left(\mathrm{mm}^{3}\right)$ & $0.8-1.4$ & $0.9-1.6$ & $0.7-1.6$ & $0.7-1.6$ \\
\hline $\mathrm{CO}_{2}(\mathrm{ppm})$ & $258-281$ & $221-250$ & $208-232$ & $185-210$ \\
\hline $\mathrm{pH}^{2}$ & $4.0-4.4$ & $4.0-4.4$ & $3.8-4.1$ & $3.6-4.0$ \\
\hline
\end{tabular}


family); and Ceratophysella ca. brevis had the highest density. Samples from elevation III contained 57 species, 5 of which were recorded only in this area, and Isotoma ca. notabilis was the most abundant. At elevation IV, 49 species were found, 9 of them, mainly from the Isotomidae family, are exclusive of this area; and Desoria ca. flora had the second highest abundance among all samples.

Table 2. Taxonomic list and total density (individuals $\mathrm{m}^{-2} \pm \mathrm{SE}$ ) of Collembola from four altitudes, at the northeast slope of Iztaccíhuatl, México.

\begin{tabular}{|c|c|c|c|c|}
\hline \multirow[t]{2}{*}{ Species } & \multicolumn{4}{|c|}{ Altitudes } \\
\hline & $2,753 \mathrm{~m}$ & $3,015 \mathrm{~m}$ & $3,250 \mathrm{~m}$ & $3,607 \mathrm{~m}$ \\
\hline \multicolumn{5}{|l|}{ Hypogastruridae } \\
\hline Hypogastrura ca. hispanica+ & 0 & 0 & $3 \pm 1$ & 0 \\
\hline Hypogastrura ca. sensilis + & 0 & 0 & $2 \pm 2$ & $1 \pm 1$ \\
\hline Ceratophysella ca. brevis + & $3 \pm 2$ & $2305 \pm 1000$ & $9 \pm 6$ & $9 \pm 8$ \\
\hline Ceratophysella ca. denticulata & 0 & $51 \pm 41$ & $5 \pm 2$ & 0 \\
\hline Ceratophysella ca. succinea + & 0 & $133 \pm 86$ & 0 & 0 \\
\hline Schoettella ca. glasgowi & 0 & 0 & 0 & $67 \pm 26$ \\
\hline Willemia ca. bedosae & 0 & $2 \pm 1$ & $16 \pm 7$ & $15 \pm 6$ \\
\hline Stenogastrura sp. & $3 \pm 2$ & $14 \pm 13$ & $2 \pm 1$ & 0 \\
\hline \multicolumn{5}{|l|}{ Odontellidae } \\
\hline Odontella ca. denticulata & 0 & $199 \pm 186$ & 0 & 0 \\
\hline Superodontella ca. conglobata & 0 & $23 \pm 16$ & 0 & 0 \\
\hline Superodontella ca. nana & 0 & $4 \pm 3$ & 0 & 0 \\
\hline Stachiomella sp. & 0 & $1 \pm 1$ & 0 & 0 \\
\hline \multicolumn{5}{|l|}{ Neanuridae } \\
\hline Friesea hoffmannorum & $11 \pm 6$ & $70 \pm 45$ & $99 \pm 20$ & $542 \pm 95$ \\
\hline Neanura muscorum & $16 \pm 6$ & $2 \pm 1$ & $1 \pm 1$ & 0 \\
\hline Americanura ca. prima & 0 & $6 \pm 2$ & $4 \pm 2$ & 0 \\
\hline Americanura ca. izabalana & 0 & $4 \pm 2$ & $14 \pm 6$ & $1 \pm 1$ \\
\hline Pseudachorutes ca. romeroi & $6 \pm 3$ & $34 \pm 14$ & $39 \pm 12$ & $19 \pm 12$ \\
\hline Pseudachorutes ca. simplex & $1 \pm 1$ & $1 \pm 1$ & $30 \pm 9$ & $19 \pm 13$ \\
\hline Micranurida pygmaea & 0 & $3 \pm 2$ & 0 & 0 \\
\hline \multicolumn{5}{|l|}{ Onychiuridae } \\
\hline Protaphorura macrodentata & $3 \pm 1$ & 0 & 0 & 0 \\
\hline Protaphorura meridiata & $1 \pm 1$ & 0 & 0 & 0 \\
\hline Mesaphorura florae & $10 \pm 4$ & 0 & $24 \pm 12$ & $2 \pm 2$ \\
\hline Mesaphorura krausbaueri & 0 & $1 \pm 1$ & 0 & 0 \\
\hline Mesaphorura macrochaeta & $664 \pm 141$ & $148 \pm 24$ & $229 \pm 46$ & $11 \pm 10$ \\
\hline Mesaphorura yosiii & $13 \pm 7$ & $11 \pm 5$ & $52 \pm 33$ & $125 \pm 62$ \\
\hline Metaphorura affinis & $189 \pm 47$ & $1 \pm 1$ & 0 & 0 \\
\hline Fissuraphorura sp. & 0 & $1 \pm 1$ & 0 & 0 \\
\hline \multicolumn{5}{|l|}{ Isotomidae } \\
\hline Folsomides chichinautzini & $18 \pm 17$ & 0 & 0 & 0 \\
\hline Proisotoma ca. alticola & $12 \pm 8$ & 0 & $8 \pm 5$ & $330 \pm 132$ \\
\hline Proisotoma frisoni & 0 & 0 & $5 \pm 5$ & 0 \\
\hline Proisotoma minuta & 0 & 0 & 0 & $14 \pm 8$ \\
\hline Proisotoma ca. sepulcralis ${ }^{1}$ & $97 \pm 83$ & $26 \pm 11$ & $85 \pm 34$ & $1 \pm 1$ \\
\hline Proisotoma ca. sepulcralis $^{2}$ & 0 & $5 \pm 3$ & $1 \pm 1$ & 0 \\
\hline Proisotoma sp. 1 & 0 & $3 \pm 2$ & $6 \pm 5$ & $1 \pm 1$ \\
\hline Proisotoma sp. 2 & 0 & 0 & $4 \pm 4$ & $1 \pm 1$ \\
\hline Proisotoma sp. 3 & 0 & $4 \pm 3$ & $1 \pm 1$ & 0 \\
\hline Proisotoma sp. 4 & 0 & 0 & 0 & $4 \pm 3$ \\
\hline Ballistura ca. obtusicauda & $2 \pm 2$ & 0 & 0 & 0 \\
\hline Folsomina onychiurina & $7 \pm 6$ & $18 \pm 9$ & $40 \pm 19$ & 0 \\
\hline Clavisotoma ca. plicicauda & $6 \pm 5$ & $44 \pm 22$ & $10 \pm 8$ & 0 \\
\hline Hemisotoma thermophila & $1 \pm 1$ & 0 & $13 \pm 8$ & $174 \pm 81$ \\
\hline Isotomurus ca. palustroides & 0 & 0 & 0 & $21 \pm 13$ \\
\hline Isotomorus ca. tricolor & $1 \pm 1$ & $1 \pm 1$ & $4 \pm 4$ & $167 \pm 60$ \\
\hline Isotomiella minor & $31 \pm 13$ & $13 \pm 5$ & $2 \pm 2$ & 0 \\
\hline Isotoma ca. subviridis & $287 \pm 60$ & $39 \pm 15$ & $41 \pm 16$ & $115 \pm 46$ \\
\hline Parisotoma ca. notabilis & $207 \pm 52$ & $549 \pm 92$ & $549 \pm 99$ & $5 \pm 3$ \\
\hline Parisotoma ca. tariva & $41 \pm 18$ & $62 \pm 21$ & $153 \pm 43$ & $38 \pm 21$ \\
\hline Desoria ca. flora & 0 & 0 & 0 & $2203 \pm 593$ \\
\hline Granisotoma comuna & 0 & 0 & 0 & $1 \pm 1$ \\
\hline
\end{tabular}


Tabela 2. Continuation...

\begin{tabular}{|c|c|c|c|c|}
\hline \multirow[t]{2}{*}{ Species } & \multicolumn{4}{|c|}{ Altitudes } \\
\hline & $2,753 \mathrm{~m}$ & $3,015 \mathrm{~m}$ & $3,250 \mathrm{~m}$ & $3,687 \mathrm{~m}$ \\
\hline \multicolumn{5}{|l|}{ Entomobryidae } \\
\hline Orchesella ca. folsomi & $1 \pm 1$ & $2 \pm 1$ & $3 \pm 2$ & 0 \\
\hline Americabrya arida & $22 \pm 8$ & $16 \pm 4$ & $54 \pm 16$ & $38 \pm 15$ \\
\hline Entomobrya ca triangularis & $21 \pm 6$ & $34 \pm 7$ & $70 \pm 19$ & $33 \pm 9$ \\
\hline Entomobrya sp. 1 & 0 & $3 \pm 2$ & $3 \pm 3$ & 0 \\
\hline Entomobrya sp. 2 & $6 \pm 4$ & $4 \pm 1$ & $18 \pm 7$ & $3 \pm 1$ \\
\hline Entomobrya sp. 3 & 0 & $7 \pm 3$ & $153 \pm 45$ & 0 \\
\hline Willowsia mexicana & $13 \pm 5$ & $22 \pm 7$ & $4 \pm 2$ & $1 \pm 1$ \\
\hline Willowsia ca. nigromaculata & $1 \pm 1$ & 0 & 0 & $6 \pm 5$ \\
\hline Seira purpurea & 0 & $1 \pm 1$ & 0 & $1 \pm 1$ \\
\hline Lepidocyrtus finus & 0 & $26 \pm 8$ & $22 \pm 6$ & $70 \pm 21$ \\
\hline Pseudosinella ca. dubia & 0 & $5 \pm 3$ & $2 \pm 1$ & $1 \pm 1$ \\
\hline Pseudosinella ca. hirsuta & 0 & 0 & $1 \pm 1$ & 0 \\
\hline Pseudosinella ca. orba & 0 & 0 & $8 \pm 6$ & 0 \\
\hline Pseudosinella ca. sexoculata & 0 & $8 \pm 4$ & $37 \pm 11$ & 0 \\
\hline Pseudosinella ca. testa & 0 & 0 & 0 & $3 \pm 2$ \\
\hline \multicolumn{5}{|l|}{ Tomoceridae } \\
\hline Plutomurus ca. californicus & $4 \pm 2$ & 0 & 0 & 0 \\
\hline \multicolumn{5}{|l|}{ Sminthurididae } \\
\hline Sminthurides ca. lepus & 0 & $1 \pm 1$ & $3 \pm 2$ & $3 \pm 3$ \\
\hline Sminthurides ca. occultus & $11 \pm 6$ & $32 \pm 12$ & $20 \pm 6$ & $220 \pm 74$ \\
\hline Sminthurides sp. 1 & $6 \pm 4$ & $16 \pm 8$ & $82 \pm 30$ & $253 \pm 92$ \\
\hline Sphaeridia pumilis & $109 \pm 74$ & $18 \pm 8$ & $47 \pm 18$ & $59 \pm 23$ \\
\hline \multicolumn{5}{|l|}{ Katiannidae } \\
\hline Polykatiana ca. intermedia & 0 & $1 \pm 1$ & $2 \pm 1$ & $2 \pm 1$ \\
\hline Sminthurinus ca. elegans & $36 \pm 14$ & 0 & 0 & $4 \pm 4$ \\
\hline Sminthurinus ca. quadrimaculatus & $1 \pm 1$ & $1 \pm 1$ & $14 \pm 10$ & $3 \pm 3$ \\
\hline Sminthurinus sp. 1 & 0 & 0 & 0 & $1 \pm 1$ \\
\hline \multicolumn{5}{|l|}{ Dicyrtomidae } \\
\hline Dicyrtomaca. mithra & 0 & $1 \pm 1$ & 0 & 0 \\
\hline Ptenothrix ca. atra & $3 \pm 2$ & 0 & $1 \pm 1$ & 0 \\
\hline Ptenothix ca. califormica & 0 & $3 \pm 2$ & $2 \pm 2$ & $5 \pm 3$ \\
\hline Ptenothix ca. renateae & $7 \pm 3$ & $1 \pm 1$ & $1 \pm 1$ & $1 \pm 1$ \\
\hline Ptenothix ca. texensis & 0 & 0 & $1 \pm 1$ & 0 \\
\hline \multicolumn{5}{|l|}{ Sminthuridae } \\
\hline Sminthurus ca. eisenii & $99 \pm 33$ & $44 \pm 14$ & $21 \pm 10$ & $107 \pm 31$ \\
\hline Sminthurus ca. incisus & $2 \pm 1$ & $9 \pm 4$ & 0 & 0 \\
\hline Sminthurus ca. fitchi & 0 & 0 & 0 & $1 \pm 1$ \\
\hline Sminthurus ca. sagittus & $2 \pm 1$ & 0 & 0 & $2 \pm 1$ \\
\hline \multicolumn{5}{|l|}{ Neelidae } \\
\hline Neelus murinus & $1 \pm 1$ & $17 \pm 5$ & $2 \pm 1$ & 0 \\
\hline Neelides minutus & $2 \pm 2$ & $27 \pm 15$ & $9 \pm 3$ & 0 \\
\hline Megalothorax incertus & $1 \pm 1$ & $16 \pm 10$ & $14 \pm 10$ & 0 \\
\hline Megalothorax minimus & $75 \pm 14$ & $144 \pm 28$ & $327 \pm 60$ & $1 \pm 1$ \\
\hline Total & $2049 \pm 4$ & $4227 \pm 13$ & $2369 \pm 3$ & $4701 \pm 9$ \\
\hline Species richnes $(\mathrm{S})$ & 45 & 58 & 57 & 49 \\
\hline Shannon diversity index $\left(\mathrm{H}^{\prime}\right)$ & 2.43 & 1.99 & 2.88 & 2.11 \\
\hline Pielou's index (J') & 0.638742 & 0.4885866 & 0.7132977 & 0.544717 \\
\hline Simpson's dominancy index $(\lambda)$ & 0.153465 & 0.321053 & 0.0985814 & 0.247268 \\
\hline
\end{tabular}

Highest diversity and equitability were found at the elevation III, followed by I, IV and II (Table 2). The $t$ analyses showed significant differences between elevation II and III $\left(\mathrm{t}_{80}=4.11 ; \mathrm{p}<0.005\right)$ and elevation III with IV $\left(\mathrm{t}_{80}=3.88 ; \mathrm{p}>0.005\right)$. The diversity and dominance had a similar pattern throughout the year, and no differences were found at elevations I, III and IV. Dominant species encountered were: Ceratophysella ca. brevis and Desoria ca. flora, at the elevations II and IV, respectively. Higher diversity at III is probably due to the lower slope, the absence of more abundant species, and relatively constant humidity throughout the year. The months of March and June were less diverse, mainly at II, probably because of the relative abundance of the dominant species, C. ca. brevis. Elevation II had the lowest diversity and the highest dominance, particularly in June (Figure 1). This elevation also had the lowest equitability, probably due to the great abundance of $C$. ca. brevis.

CCA analyses showed that the canonic axes 1 and 2 explained $59.4 \%$ of the variance. $\mathrm{CO}_{2}$ best explained axis $1(r=0.70)$, together with elevation $(r=0.69)$, while 
slope was better related with axis $2(\mathrm{r}=-0.77)$ (Figure 2). The Monte-Carlo test showed significant differences: Americanura ca. prima, Clavisotoma ca. plicicauda, Seira purpurea, Sminthurus ca. incisus, Neelus murinus and Megalothorax incertus were better

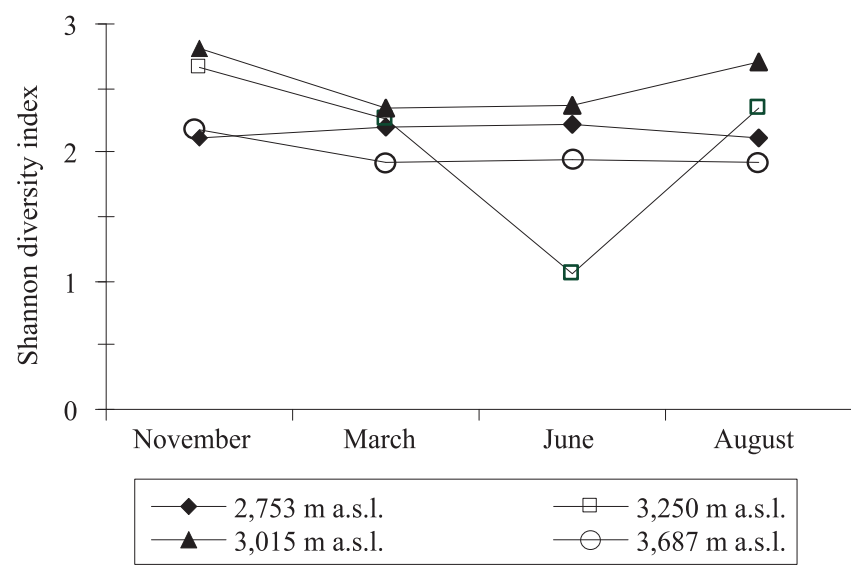

Figure 1. Annual variation of the diversity of Collembola from Iztaccíhuatl Volcano, Mexico, at four elevations.

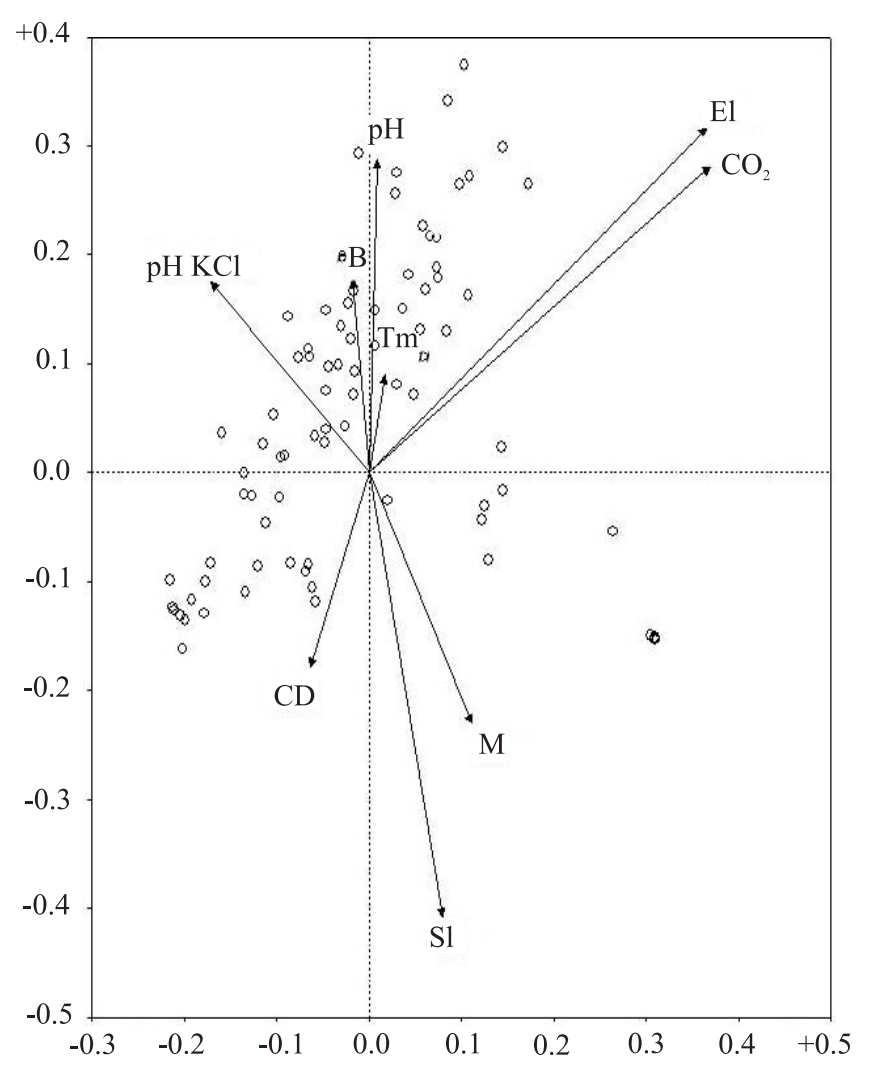

Figure 2. Canonical correspondence analysis of Collembola species collected along an altitudinal gradient, at Iztaccíhuatl Volcano, México. Sl, slope; M, humidity; CD, collection date; Tm, temperature; B, biotope (soil or litter); El, altitude. correlated with axis 1; and Pseudachorutes ca. romeroi, Proisotoma sp. 1, Proisotoma sp. 4, Orchesella ca. folsomi, Pseudosinella ca. testa, Sminthurus ca. eisenii and Megalothorax minimus with axis 2.

The results showed new distributional records for five species (Proisotoma frisoni, Proisotoma minuta, Folsomides chichinautzini, Folsomina onychiurina, and Lepidocyrtus finus). Odontellidae, Onychiuridae, Sminthuridae and Neelidae were recorded for the first time in the area. Genera and species diversity were higher in our work than the one reported by Cutz-Pool et al. (2008), and number of species was also higher than in the neighboring Popocatépetl Volcano (Palacios-Vargas, 1985). These families are euedaphic and represent important new discoveries for the Collembola communities in the area.

Different and exclusive species were found at each elevation: five at I, nine at II, five at III, and eight at IV. Desoria ca. flora seems to be a good indicator of altitude, as is was abundantly found throughout the year at the highest elevation.

Bondarenko-Borisova \& Gandul (2001) pointed out that Odontellidae is found in spruce forests, with little perturbation. This appeared to be the case in our study as well; this family was not found at elevation I, probably because it was the most disturbed.

Compared with the earlier study of Cutz-Pool et al. (2008), we observed higher species diversity in the same area of the Iztaccíhuatl Volcano. In fact, about half of the species encountered were new to science and must be still described.

The abundance and diversity of Collembola assemblage is due to the interaction of different variables, which vary along temporal and altitudinal gradients. In our study, altitude and humidity played an important role in the establishment of different assemblages; the highest density of Collembola was recorded at the highest elevation (IV). Furthermore, slope and $\mathrm{CO}_{2}$ were also important factors. The importance of $\mathrm{CO}_{2}$ for species assemblages of springtails is a factor, which had not been mentioned in previous studies.

\section{Conclusions}

1. $\mathrm{CO}_{2}$ and altitude are factors of extreme importance for the establishment of the Collembola species.

2. The degree of slope is linked to humidity, where the species assemblage varied considerably in spite of $\mathrm{CO}_{2}$, but not the altitude. 
3. Desoria ca. flora only at $3,687 \mathrm{~m}$ elevation indicates that this species is specially adapted to the unique characteristics of this site (low air humidity and temperature).

4. Some Collembola species are able to adapt to the continuous disturbance of their habitat at $2,753 \mathrm{~m}$ elevation.

\section{Acknowledgments}

To Leopoldo Cutz, Aldo Bernal, Carmen Maldonado, Ricardo Iglesias and Leonardo González, for field work assistance; to Consejo Nacional de Ciencia y Tecnología (Mexico), for scholarship to AGG.

\section{References}

BONDARENKO-BORISOVA, I.V.; GANDUL, N.G. 2002. The fauna of springtails (Collembola) from the forest ecosystems of South-Easth Ukranie. Vestnik Zoologii, v.36, p.11-21, 2002.

CHRISTIANSEN, K.A.; BELLINGER, P.F. The Collembola of North America North of the Rio Grande: a taxonomical analysis. Iowa: Grinnell Collage, 1998. 1520p.

CUTZ-POOL, L.Q.; PALACIOS-VARGAS, J.G.; CASTAÑO-MENESES, G. Estructura de la comunidad de colémbolos (Hexapoda: Collembola) en musgos corticícolas en un gradiente altitudinal de un bosque templado subhúmedo. Revista de Biología Tropical, v.56, p.739-748, 2008.

D'HAESE, C. Willemia anophtalma-group (Collembola: Hypogastruridae): systematics, new species, distribution and habitats. European Journal of Entomology, v.95, p.581-592, 1998.

HEANEY, L.R. Small mammal diversity along elevational gradients in the Philippines: an assessment of patterns and hypotheses. Global Ecology and Biogeography, v.10, p.15-39, 2001.

HOWELL, D.C. Statistical methods for psychology. $5^{\text {th }}$ ed. California: Duxbury, 2002. 802p.

JANSSENS, F. Checklist of Collembola of the world. 2007. Available at: <http://www.collembola.org/taxa/collembo.htm>. Accessed on: 01 July 2007.
JING, S.; SOLHØY, T.; HUIFU, W.; VOLLANT, T.I.; RUMEI, $\mathrm{X}$. Differences in soil arthropod communities along a high altitude gradient at Shergyla Mountain, Tibet, China. Arctic, Antarctic, and Alpine Research, v.37, p.261-266, 2005.

JORDANA, R.; ARBEA, J.I.; SIMÓN, C.; LUCIÁÑEZ, M.J. Collembola Poduromorpha. In: RAMOS, M.A.; ALBA, J.; BELLÉS, X.; GOSÁLBEZ, J.; GUERRA, A.; MACPHERSON, E.; SERRANO, M.F.; TEMPLODO, J. (Ed.). Fauna Ibérica. Madrid: Museo Nacional de Ciencias Naturales, 1997. v.8, p.233.

MAGURRAN, A.E. Ecological diversity and its measurement. New Jersey: Princeton University, 1988. p.425.

MARI-MUTT, J.A.; PALACIOS-VARGAS, J.G. Americabrya, a new genus of Entomobryidae (Collembola), with a redescription of A. arida (Christiansen and Bellinger) based on Mexican specimens and descriptive notes for A. epiphyta (Loring). Journal of the New York Entomological Society, v.95, p.99-108, 1987.

O'DONNELL, S.; KUMAR, A. Microclimatic factors associated with elevational changes in army ant density in tropical montane forest. Ecological Entomology, v.31, p.491-498, 2006.

PALACIOS-VARGAS, J.G. Artrópodos del Popocatépetl. 1985. 185p. Thesis (Doctoral) - Universidad Nacional Autónoma de México, Ciudad de México.

PALACIOS-VARGAS, J.G. On Friesea (Collembola: Neanuridae) from Mexico and description of a new species in the genus. Journal of the Kansas Entomological Society, v.55, p.46-51. 1982.

SADAKA, N.; PONGE, J.F. Soil animal communities in holm oak forests: influence of horizon, altitude and year. European Journal of Soil Biology, v.39, p.197-207, 2003.

SÁNCHEZ M.A.V. Revisión del género Megalothorax (Collembola: Neelidae) en México. 1999. 70p. Thesis (Undergraduate) - Universidad Nacional Autónoma de México, Ciudad de México.

TER BRAAK, C.J.K.; SMILAUER, P. CANOCO referent manual and user's guide to Canoco for Windows: software for canonical community ordination. Version 4. Ithaca: Micropunter Power, 1998. p.352.

VAN REEUWIJK. L.P. (Ed.). Procedures for soil analysis. $6^{\text {th }} \mathrm{ed}$. Wageningen: International Soil Reference and Information Centre. Rome: Food and Agricultural Organization of the United Nations, 2002.

ZAR, J.H. Biostatystical analysis. 2.ed.New Jersey: Prentice-Hall, 1984. 545p.

Received on September 29, 2008 and accepted on July 8, 2009 